Sains Malaysiana 50(8)(2021): 2329-2341

http://doi.org/10.17576/jsm-2021-5008-16

\title{
Characterization, Antioxidant and $\alpha$-Glucosidase Inhibitory Activity of Collagen Hydrolysate from Lamuru (Caranx ignobilis) Fishbone
}

(Pencirian, Antioksidan dan Aktiviti Perencatan $\alpha$-Glukosid Kolagen daripada Tulang Ikan Lamuru (Caranx ignobilis))

\author{
Syamsu NuR*, Yogillverd Wierson, Yulia, Fitriyanti Jumaetri Sami, Megawati, Andi Nur Aisyah, \\ MARWATI \& SAHIBUDDIN A. GANI
}

\begin{abstract}
The Lamuru fish (Caranx ignobilis) is mostly found in tropical waters of the indo-pacific region, namely Indonesia. It is believed to contain collagen and this study aims to isolate collagen from its bone and determine the collagen's antioxidant and $\alpha$-glucosidase inhibitory activity. In our study, the collagen was extracted using acetic acid which was hydrolyzed by collagenase enzyme from Clostridium histolyticum at a temperature of $37{ }^{\circ} \mathrm{C}$, and $\mathrm{pH}$ 7.0. During hydrolysis, the degree of hydrolysis $(D H)$ was calculated and collagen hydrolysates were characterized by SDS-PAGE, UVVisible spectroscopy and FT-IR spectroscopy. After characterization, the collagen hydrolisate of lamuru (CHL) fish was analyzed for its antioxidant properties and $\alpha$-glucosidase inhibitory activity. The result shows that a higher percentage degree of hydrolysis was obtained, 31.17\%, at 120 min of hydrolysis. The CHL characterization by SDS-PAGE Showed its molecular weight ranging from 35,000-180,000 Daltons and identified the collagen as type I. The UV-Vis analysis of CHL provided a maximum absorbance at a wavelength of $233 \mathrm{~nm}$. At the same time, the FT-IR analysis showed the presence of amides I, II, and III, which confirms the formation of the collagen triple helix. For its bioactivity assay, the CHL shows that CHL provided DPPH radical reduction activity reaching $51.45 \pm 1.24 \%\left(\mathrm{CC}_{50}\right.$ at $\left.485.9 \mu \mathrm{g} / \mathrm{mL}\right)$. The ferric reduction antioxidant power of CHL (FRAP value) showed a significant reduction of Fe ${ }^{3+}$ to $\mathrm{Fe}^{2+}$ with a value of $711.27 \mu \mathrm{M} / \mathrm{g}$. The CHL inhibition activity of $\alpha$-glucosidase enzyme $I_{50}$ was determined to be $574 \mu \mathrm{g} / \mathrm{mL}$. Based on the antioxidant bioactivity and $\alpha$-glucosidase inhibition, the collagen peptide enables its use as a therapeutic development for a variety of disorders caused by oxidative stress, such as diabetes mellitus.
\end{abstract}

Keywords: a-glucosidase inhibitory; antioxidant; Caranx ignobilis; characterization; collagen hydrolysate (CHL)

ABSTRAK

Ikan Lamuru (Caranx ignobilis) adalah sejenis ikan yang hidup di perairan Indo-Pasifik khasnya Indonesia. Ia dipercayai mengandungi bahan kolagen dan kajian ini bertujuan untuk mengasingkan bahan kolagen daripada tulang ikan Lamuru serta menentukan aktiviti antioksidan dan perencatan oleh $\alpha$-glukosid. Dalam kajian ini, kolagen daripada tulang ikan lamuru diekstrak menggunakan asid asetik dan kemudian dihidrolisis menggunakan enzim kolagenase daripada Clostridium histolyticum pada $37^{\circ} \mathrm{C}$, pH 7.0. Semasa hidrolisis, tahap hidrolisis (DH) telah dapat ditentukan. Kolagen tulang ikan Lamuru (CHL) dicirikan oleh SDS-PAGE, spektroskopi UV boleh nampak dan spektroskopi FT-IR. Setelah pencirian, CHL dianalisis aktiviti menghambat antioksidan dan a-glukosid. Keputusan menunjukkan bahawa tahap peratusan hidrolisis lebih tinggi berlaku pada 120 min dengan peratusan kadar hidrolisis sebanyak $31.71 \%$. Pencirian CHL oleh SDS-PAGE memperoleh berat molekul purata antara 35,000-180,000 Dalton dan menunjukkan ia adalah merupakan jenis kolagen I. Analisis UV boleh nampak CHL menyediakan penyerapan maksimum pada panjang gelombang $233 \mathrm{~nm}$. Pada masa yang sama, analisis FT-IR mengesan kehadiran amides I, II dan III yang menunjukkan formasi gandaan tiga heliks kolagen. Untuk ujian bioaktiviti, CHL menunjukkan bahawa CHL memberi aktiviti pengurangan radikal DPPH mencapai $51.45 \pm 1.24 \%\left(I C_{50}\right.$ pada $\left.485.9 \mu \mathrm{g} / \mathrm{mL}\right)$ dan kuasa antioksidan penurunan besi CHL (nilai FRAP), Fe ${ }^{3+}$ hingga Fe ${ }^{2+}$ bernilai $711.27 \mu \mathrm{M} / \mathrm{g}$. CHL daripada tulang ikan mampu memerencat aktiviti enzim $\alpha$-glucosid dengan nilai $I C_{5} 0574 \mu \mathrm{g} / \mathrm{mL}$. Berdasarkan pengujian bioaktiviti antioksidan dan penghambatan alfa 
glukosid sehingga kolagen peptida membolehkannya digunakan sebagai pengembangan terapi berkaitan dengan pelbagai sebab yang disebabkan oleh tekanan oksidatif seperti diabetes mellitus.

Kata kunci: Antioksidan; Caranx ignobilis; kolagen hidrolisat (CHL); pencirian; perencatan a-glukosid

\section{INTRODUCTION}

Caranx ignobilis, more commonly known by the people of Sulawesi-Indonesia as the lamuru fish, is a type of reef fish that has potential to be developed as medicine, with numbers that are quite large in Indonesian waters. In addition, consumption of this fish has become popular for many people. Lamuru fish has been used in the formation of food products, but the bone and skin of the lamuru fish have not been used optimally, even though this fish has the potential as an alternative source of collagen.

Collagen is a part of the extracellular protein matrix, with a triple helical conformation that plays an important role in maintaining the structure of various tissues; collagen is a major component of various connective tissues, such as the skin, bones, tendons, blood vessels, basal membranes, cartilage and teeth, and contributes about $25-30 \%$ of the total animal protein content. Collagen, with a triple-helical conformation, has been identified to have as many as 29 variants, namely type I-XXIX (Liu et al. 2007; Pati et al. 2010). Collagen type I is the most abundant and can be found in all vertebrate connective tissues, with wide application in various fields such as the food, biomedical, pharmaceutical, and cosmetics industries (Hoyer et al. 2014).

Collagen is a type of protein hydrolysate that has bioactive peptides containing 2-20, or even more, amino acid residues which have many functions for industrial purposes and human health (Haque \& Chand 2008). Peptides in general do not show any effects as a protein sequence, but they show more activities when undergoing hydrolysis into protein hydrolysates. Those activities include, but are not limited to, antimicrobial (Abuine et al. 2019; Ulagesan et al. 2018), antihypertensive (Zhuang et al. 2012), antioxidant (Hong et al. 2019; Kim \& Mendis 2006) and antidiabetic (Konrad et al. 2014whey protein concentrate (WPC-80; Yu et al. 2011).

The main source of commercial collagen is generally the bones of cattle and pigs. The use of bovine bones as a source of collagen began to cause concern among producers due to the outbreak of bovine spongiform encephalopathy (BSE), transmissible spongiform encephalopathy (TSE) and foot and mouth disease (FMD) (Zhang et al. 2010). Therefore, we required an alternative material that could be used as a source of collagen, one of which is the waste of aquatic organisms. Waste from aquatic organisms, such as bones, skin, and fish scales, is known to contain a lot of collagen. Additionally, collagen from fish skin (food grade) is known to be better absorbed in the human body and is often used in biotechnology (Gómez-Guillén et al. 2002).

In recent years, the development of antioxidant and antidiabetic drugs has been carried out mainly from natural and animal compounds. Several studies have reported that collagen hydrolysates from other sources provide activities such as antioxidant, thereby inhibiting oxidative degradation by reacting with free radicals (León-López et al. 2019). Collagen hydrolysate provides antioxidant activity via the mechanism of electron donation or hydrogen transfer (Lorenzo et al. 2018). The antioxidant activity of collagen hydrolysates is generally associated with the molecular weight of the peptide. Peptides with 2 to 10 amino acid residues have a molecular weight of about $10 \mathrm{KDa}$, meaning that the inhibition of free radicals can occur (Zhao et al. 2018).

Several studies have reported that collagen hydrolysates from different sources provide strong antioxidant activity, such as collagen peptides obtained from skipjack tuna (Katsuwonus pelamis) bone (Ding et al. 2019), snakehead (Channa striatus) fish skin (Haniffa et al. 2014), Allaska Pollack fish skin (Byun \& Kim 2001), and cod fish skin (Carvalho et al. 2018). Besides antioxidants, collagen hydrolysates also provide antidiabetic effects in which the collagen hydrolysates from bone or fish skin were found to inhibit the DPP-IV enzyme and stimulate the secretion of GLP1 when given to male rats orally and intraperitoneally (Iba et al. 2016). However, research into the ability of collagen hydrolysate from lamuru fishbone to inhibit free radicals and the $\alpha$-glucosidase enzyme has not been found; therefore, it is necessary to undertake research into this type of collagen hydrolysate as an antioxidant and inhibitor of the $\alpha$-glucosidase enzyme. Thus, the objectives 
of our study were the isolation and characterization of collagen peptides from lamuru fishbone and determining the antioxidant activity of collagen peptides from lamuru fishbone using DPPH radical scavenging and iron reduction, as well as to determine its bioactivity profile against the inhibition of $\alpha$-glucosidase enzymes. It is hoped that the results of this study will provide an overview of supportive therapy for diseases associated with oxidative stress such as diabetes mellitus.

\section{MATERIALS AND METHODS}

The materials used were acetic acid, hydrochloric acid, trichloroacetic acid (TCA, Japan), phosphate buffer saline, bovine serum album (BSA), Folin Ciocalteu, potassium sodium tartrate, potassium bromide, sodium chloride, sodium hydroxide, sodium carbonate, tris- $\mathrm{HCl}$, ninhydrin reagent (Merck, Germany), $\alpha$-glucosidase, collagenase (Sigma Aldrich, USA), and p-nitrophenyl $\alpha$-D-glucopyranoside (Sigma Aldrich, USA). Analytical grade chemicals and reagents were used in this experiment.

Lamuru fish (Caranx ignobilis) were obtained from 'Paotere' fish markets in Makassar, South Sulawesi, Indonesia, which have an average fish size of $2 \mathrm{~kg}$, and they were brought to the laboratory. The lamuru was dissected and the fishbone was separated and stored at $-20{ }^{\circ} \mathrm{C}$ prior to use.

\section{COLLAGEN EXTRACTION}

The collagen from lamuru fish samples was extracted using the methods reported by Mocan et al. (2011) and Ogawa et al. (2003) with slight modification. All procedures were carried out at room temperature, with the following steps for degreasing and the extraction of collagen. Firstly, lamuru fishbone samples were separated from impurities and the removal of non-collagen proteins and fat was achieved by soaking samples in $0.1 \mathrm{M} \mathrm{NaOH}$ solution at a ratio of $1: 10(\mathrm{w} / \mathrm{v})$. This immersion was carried out for $3 \times 24 \mathrm{~h}$ and the solvent was replaced with fresh $0.1 \mathrm{M} \mathrm{NaOH}$ every $24 \mathrm{~h}$. The fishbone was then washed with distilled water until the sample reached $\mathrm{pH}$ 7.0.

Secondly, the extraction of acid soluble collagen (ASC) was carried out by soaking samples in $1 \mathrm{M}$ acetic acid with a ratio of $1: 15(\mathrm{w} / \mathrm{v})$ for $3 \times 24 \mathrm{~h}$ at $4{ }^{\circ} \mathrm{C}$. The mixtures were filtered by filter paper to separate the residue and filtrates. Then, the residue was re-extracted under the same conditions. The filtrates were collected and precipitated via a salting out process with $\mathrm{NaCl}$ to a final concentration of $0.9 \mathrm{M}$ in the presence of tris- $\mathrm{HCl}$ buffer at $\mathrm{pH}$ 7.0. The precipitate was collected by centrifuging at $10,000 \mathrm{~g}$ for $1 \mathrm{~h}$ at $4{ }^{\circ} \mathrm{C}$ by using a refrigerated centrifuge. The residue was dissolved in $1 \mathrm{M}$ acetic acid with a minimum volume and lyophilized. The yield of ASC was calculated from the percentage of the dry weight of collagen extracted in comparison to the wet weight of the lamuru fishbone.

\section{DEGREE OF COLLAGEN HYDROLYSIS}

One gram of collagen sample was dissolved in $100 \mathrm{~mL}$ of distilled water and then heated at $60^{\circ} \mathrm{C}$ for $15 \mathrm{~min}$. Then, the mixtures were filtered and the filtrate obtained was further used as the substrate. Furthermore, $0.1 \mathrm{U} / \mathrm{mg}$ of the collagenase enzyme (from Clostridium histolyticum) was dissolved in a Tris- $\mathrm{HCl}$ buffer at $\mathrm{pH}$ 7.0. Then, the enzyme was put into the substrate solution and stirred for 0,30 , $60,90,120$, and $150 \mathrm{~min}$. The enzyme was deactivated by heating at a temperature of $50-60{ }^{\circ} \mathrm{C}$, before being filtered and lyophilized (Bousopha et al. 2016). The degree of collagen hydrolysis was determined based on the method by Silvestre et al. (2013) with the precipitation of $20 \%$ trichloroacetic acid (TCA) to produce $10 \%$ dissolved protein fraction and $10 \%$ insoluble protein fraction. Then, $500 \mu \mathrm{L}$ of frozen collagen samples that had been thawed at room temperature was added to $500 \mu \mathrm{L}$ of $20 \%$ TCA, before being homogenized and incubated at $4{ }^{\circ} \mathrm{C}$ for $30 \mathrm{~min}$. The mixture was then centrifuged at 10,000 $\mathrm{g}$ for $30 \mathrm{~min}$, and the contents of dissolved and total protein were analyzed according to Lowry et al. (1951), where bovine serum albumin (BSA) was used as standard. The degree of hydrolysis was calculated based on the formula:

$$
\text { DH }(\%)=\frac{\text { Soluble protein in } 10 \% T C A}{\text { Total Protein }} \times 100
$$

\section{CHARACTERIZATION OF CHL BY SDS-PAGE}

The characterization of collagen hydrolysate was evaluated in terms of the molecular weight of the peptide chain in the hydrolysate from lamuru fishbone by sodium dodecyl sulfate-polyacrylamide gel electrophoresis (SDS-PAGE), as described by Mahboob (2014). First, the sample was denatured by dissolving the $\mathrm{CHL}$ in $0.02 \mathrm{M}$ 
sodium phosphate containing $1 \%$ SDS and $3.5 \mathrm{M}$ urea. The mixtures were centrifuged at $10,000 \mathrm{~g}$ for $10 \mathrm{~min}$ at room temperature and then the supernatant was mixed with buffer (0.5 M Tris-HCl, pH 6.8, containing 4\% SDS, and $20 \%$ glycerol) at a ratio of $1: 1(\mathrm{v} / \mathrm{v})$. Second, the mixtures and markers were loaded onto a polyacrylamide gel and a constant current of $20 \mathrm{~mA} / \mathrm{gel}$ was passed through it for $75 \mathrm{~min}$. The gel was stained with $0.05 \%(\mathrm{w} / \mathrm{v})$ Coomassie Brilliant Blue R-250 to locate the protein bands; the staining was performed overnight.

\section{CHARACTERIZATION OF CHL BY FTIR AND UV ABSORPTION SPECTRUM}

Characterization of CHL by Fourier transform infrared (FTIR) spectroscopy and ultraviolet (UV) absorption spectroscopy was evaluated based on Zhao et al. (2018). FTIR spectra were obtained using the $\mathrm{KBr}$ disc method, and the mixture ratio of weight was about 1:25 (sample:KBr). The spectra were assayed by an infrared spectrophotometer at 4000 to $400 \mathrm{~cm}^{-1}$ (Shimadzu). The UV absorption spectrum of CHL was measured using an ultraviolet spectrophotometer (Shimadzu). CHL (10 mg) was dissolved in $10 \mathrm{~mL}$ of $0.5 \mathrm{M}$ acetic acid. UV spectra were measured between 200 and $600 \mathrm{~nm}$ at a scan speed of $2 \mathrm{~nm} / \mathrm{s}$ with an interval of $1 \mathrm{~nm}$.

\section{DPPH RADICAL SCAVENGING ASSAY}

The DPPH radical scavenging assay was adopted from the method by Nur et al. (2019) with slight modifications. In summary, $0.4 \mathrm{mM}$ DPPH solution and various concentrations of $\mathrm{CHL}$ with a serial dilution from 100$500 \mu \mathrm{gmL}^{-1}$ were prepared. Each serial dilution of sample solution was added to $1 \mathrm{~mL}$ of DPPH solution. The mixture was made up to $5 \mathrm{~mL}$ with ethanol in the flask. The mixture was left to stand for $30 \mathrm{~min}$ at room temperature and the absorbance was measured with a UV-Vis spectrophotometer at a wavelength of $515 \mathrm{~nm}$. Antioxidant activity was calculated based on the percentage of inhibition of DPPH activity by samples compared to DPPH solutions (blank solution) without sample solutions. The $\mathrm{IC}_{50}$ value was determined based on linear regression equations obtained from plots of the percentage inhibition vs. the concentration of sample solution. The percentage of DPPH radical scavenging activity was measured using the formula:

Percentage of radical scavenging activity $=\frac{(\text { Abs CHL }- \text { Abs blank })}{\text { Abs blank }} \times 100 \%$
FERRIC REDUCING ANTIOXIDANT POWER (FRAP) ASSAY

The FRAP assay was analyzed based on the coloring method by Nur et al. (2019). Ferric chloride solution (3 $\mathrm{mM}$ in $5 \mathrm{mM}$ citric acid) and TPTZ solution (1 $\mathrm{mM}$ in $0.05 \mathrm{M}$ hydrochloric acid) as reagents and ferrous sulfate as a standard solution were prepared. Then, $500 \mu \mathrm{L}$ of the CHL was added to $100 \mu \mathrm{L}$ ferric chloride solution and 2 $\mathrm{mL}$ TPTZ solution. The sample mixture was measured at $615 \mathrm{~nm}$ and the absorbance data were calculated against a series of concentrations of ferrous sulfate as a standard curve and recorded as an equivalent to $\mu \mathrm{M} \mathrm{Fe}^{2+} / \mathrm{g}$ sample. The FRAP value is the percentage of reduction of $\mathrm{Fe}^{3+}$ to $\mathrm{Fe}^{2+}$ by the sample with $\mathrm{FeSO}_{4}$ expressed as $\mu \mathrm{M} / \mathrm{g}$ of dried collagen hydrolysate.

\section{ALPHA GLUCOSIDASE INHIBITORY ACTIVITY}

Alpha glucosidase inhibitory activity was determined according to Elya et al. (2012). In this study, $\alpha$-glucosidase (0.5 unit $\left.\mathrm{mL}^{-1}\right), 0.1 \mathrm{M}$ phosphate buffer $\mathrm{pH} 6.9$ containing bovine serum albumin, $p$-nitrophenyl- $\alpha$ D-glucopyranoside (PNPG) $5 \mathrm{mM}$ as the substrate and acarbose as the positive control were prepared. Then, 10 $\mu \mathrm{L}$ of $\mathrm{CHL}$ and acarbose in various concentrations were dissolved in buffer solution. Each sample and acarbose solution with different concentrations were placed into the welled plate and substrate solution was added before being incubated at $37{ }^{\circ} \mathrm{C}$ for $15 \mathrm{~min}$. Subsequently, the mixture was added with $20 \mu \mathrm{L}$ of enzyme solution $0.5 \mathrm{U}$ $\mathrm{mL}^{-1}$ and incubated at $37{ }^{\circ} \mathrm{C}$ for $15 \mathrm{~min}$. The enzymatic reaction was stopped by adding $80 \mu \mathrm{L}$ of $0.2 \mathrm{M}$ sodium carbonate $\left(\mathrm{Na}_{2} \mathrm{CO}_{3}\right)$ solution. The absorbance of the test solution into the well plate was read in the microplate reader at $405 \mathrm{~nm}$. The level of enzyme resistance by the CHL was expressed in the following formula:

Percentage of inhibition $=\frac{A b s \text { blank }- \text { Abs CHL }}{\text { Abs blank }} \times 100 \%$

\section{RESUlTS AND DiscUSSION}

EXTRACTION AND ISOLATION OF COLLAGEN FROM FISH BONE

This research was carried out with the process of the removal of non-collagen protein and impurities such as fat in fishbone so that collagen dissolves easily when 
extracted through immersion with an alkaline solution. The use of alkaline solution $(\mathrm{NaOH})$ was chosen as it is more effective at removing non-collagen proteins with very little collagen lost (Zhou \& Regenstein 2005). This is because non-collagen proteins from lamuru fish have already been removed, and soaking the sample with $\mathrm{NaOH}$ also causes the helical bonding of collagen to begin to stretch, so that it can bind water and make the bone structure softer. On the other hand, collagen is also a connective tissue of proteins that is more difficult to extract than other proteins, meaning that non-collagen proteins will dissolve first during the removal by using $\mathrm{NaOH}$. The next step was immersion using an acetic acid solution, which aims to obtain a high yield of collagen. In the extraction with acetic acid, there is a material change where immersion in the acid causes the bloating of bones, and the bones become softer due to the entry of solvent into the collagen fibers. This is important because it can support the collagen extraction process through the disruption of non-covalent bonds and ultimately facilitate extraction and increase collagen solubility (Zhou \& Regenstein 2005). The filtrate obtained was then precipitated via a saltingout process using $\mathrm{NaCl}(0.9 \mathrm{M})$. The addition of high concentrations of salt will cause salting out, where salt binds the water and causes the aggregation of proteins so that protein molecules will settle as wet collagen residues (Zayas 1997). The precipitated protein was then freezedried and a collagen yield value of $6.6 \%$ was achieved.

\section{DEGREE OF HYDROLYSIS (DH)}

The dried collagen that was obtained was then treated with enzymatic digestion hydrolysis so that it could release amino acid peptides from collagen proteins and form collagen hydrolysates (Ulagesan et al. 2018). In our research, the hydrolysis of collagen from lamuru fishbone was carried out using the enzyme collagenase obtained from Clostridium histolyticum. Nasri et al. (2013) reported that the success of the hydrolysis process and the resulting amino acid content depends on the enzyme used and the hydrolysis time. Determination of the degree of hydrolysis (DH) can be used as an indicator of the magnitude of the peptide bond undergoing breakage. During hydrolysis, proteolysis monitoring parameters were determined at various times, i.e. at 0 to $150 \mathrm{~min}$ with 30 min intervals. The results of the DH obtained can be seen in Figure 1.

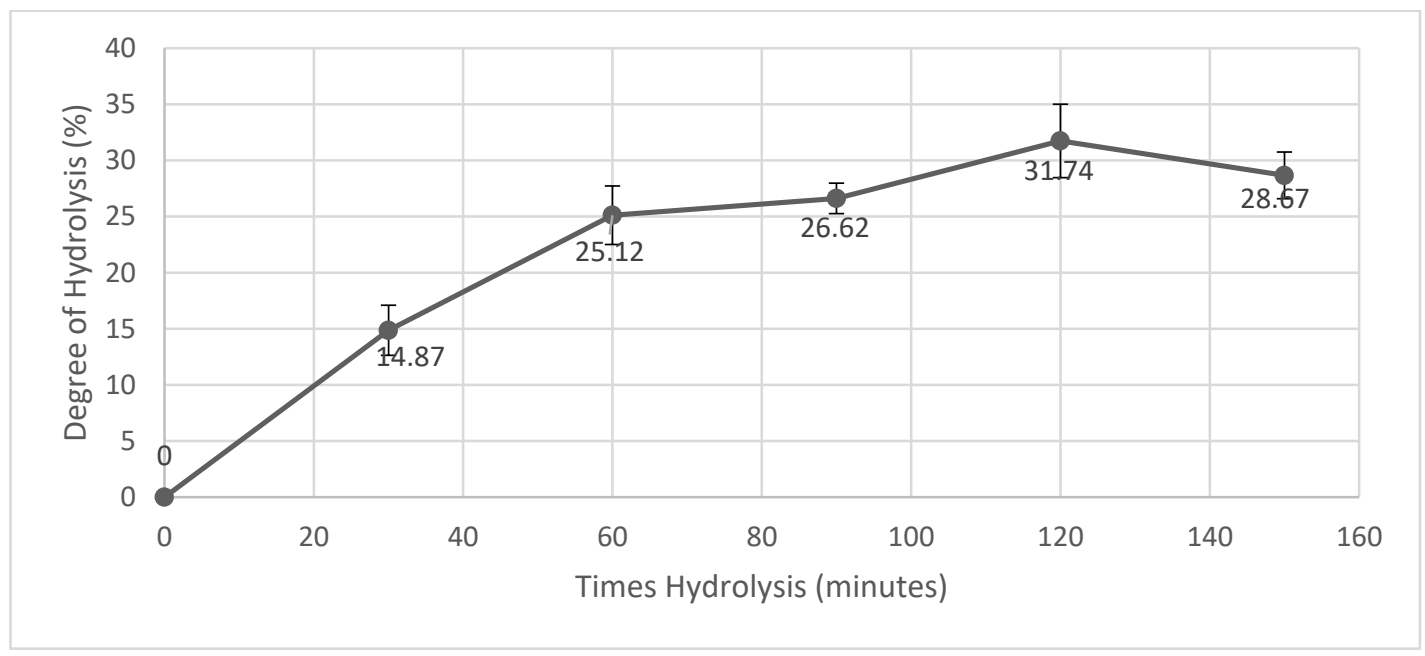

FIGURE 1. Degree of hydrolysis graph from fishbone 
Figure 1 shows that the longer the hydrolysis time, the higher the percentage degree of hydrolysis; the peak of hydrolysis occurred at $120 \mathrm{~min}$, with a percentage of the degree of hydrolysis of $31.71 \%$, while at $150 \mathrm{~min}$, there was a decrease in the percentage of the degree of hydrolysis by $28.82 \%$. In this case, it can be seen that the substrate has been completely bound to the enzyme and the enzyme has been saturated with the substrate. According to deMan (1999), the process of converting collagen to collagen hydrolysates involves three changes, namely breaking the limited number of peptide bonds to shorten the chain, breaking or disrupting a number of side bonds between chains and changing the configuration of the chain. Meanwhile, according to Poppe (1992), the conversion of water-insoluble collagen to water-soluble collagen hydrolysates causes the breaking of hydrogen bonds between the three free chains.

\section{CHL GEL ELECTROPHORESIS PROFILE FROM FISHBONE}

The results obtained from gel electrophoresis are in the form of separated protein bands based on differences in molecular weight equivalent to the length of the protein chain. Figure 2 shows the pattern of electropherogram bands, where as many as four clearly visible protein bands with similarities to markers (BIO 5150) were found. There are two major bands, namely band I and IV, with molecular weights in the range of $135-180 \mathrm{kDa}$ and $25-$ $35 \mathrm{kDa}$, respectively, whereas the other two minor bands (the figures unclear) are bands II and III with molecular weights in the range of $100-135 \mathrm{kDa}$ and $35-48 \mathrm{kDa}$, respectively. Band II shows the existence of alpha $(\alpha)$ chains, which may contain $\alpha 1$ and $\alpha 2$. In contrast, on band I with the high molecular weight, a beta $(\beta)$ chain is visible, which shows that there are cross-links in the protein molecules (Jamilah et al. 2013; Ogawa et al. 2003). Based on the band pattern, CHL has an average molecular weight ranging from 35,000-180,000 Daltons and is a type I collagen. These results are similar to the molecular weight of collagen from different sources in the studies of Ogawa et al. (2003), Liang et al. (2014), and Zhao et al. (2018).

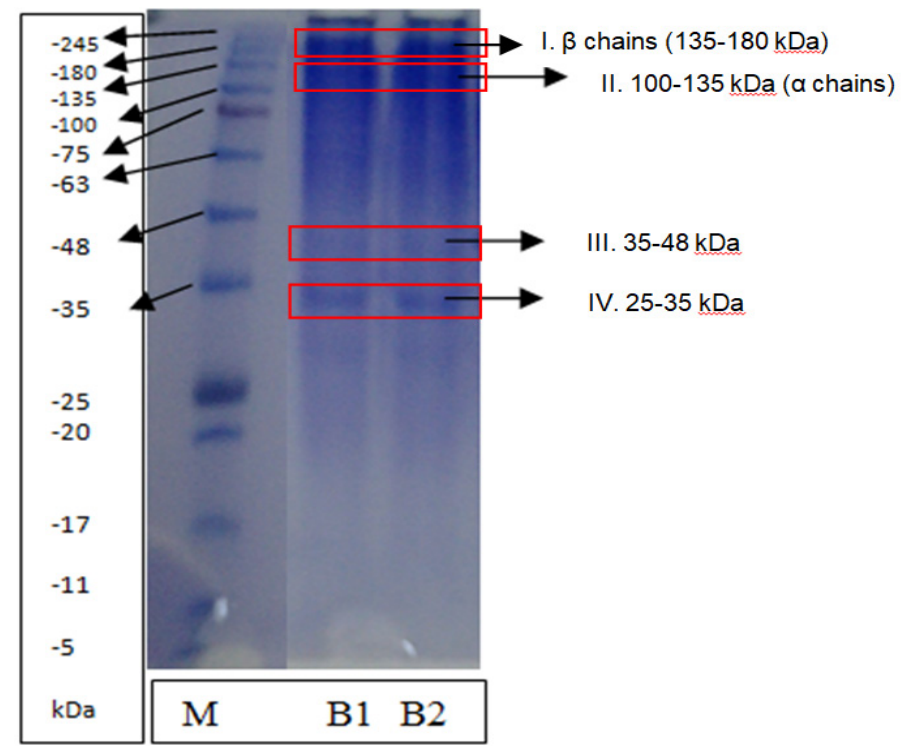

FIGURE 2. SDS-PAGE pattern of CHL from fishbone (line $\mathrm{M}=$ marker BIO 5150, line B1/B2 = CHL fishbone (two replicates) 


\section{UV SPECTRA ABSORPTION OF CHL FROM FISHBONE}

Figure 3 shows the results of CHL characterization using a UV-Vis spectrophotometer at a wavelength of 200-300 $\mathrm{nm}$. The measurement results for CHL in $0.1 \mathrm{M}$ acetic acid provide maximum absorbance at a wavelength of $233 \mathrm{~nm}$. This indicates the existence of a spectrum of polypeptide bonds in collagen where the wavelength uptake for collagen is in the range from $200-250 \mathrm{~nm}$. The same thing was reported by Liu et al. (2007) and Zhang et al. (2010), in collagen obtained from catfish and silver carp, respectively, who showed an absorbance at wavelengths of 232 and $230 \mathrm{~nm}$, respectively. The maximum absorbance at 220-240 nm may be associated with the groups $\mathrm{C}=\mathrm{O}$, $-\mathrm{COOH}$, and $\mathrm{CONH}_{2}$ in polypeptide chains of collagen. The absence of a bonding spectrum at a wavelength of $280 \mathrm{~nm}$ indicates that collagen does not contain the amino acid tryptophan (Pal \& Suresh 2017; Zhao et al. 2018).

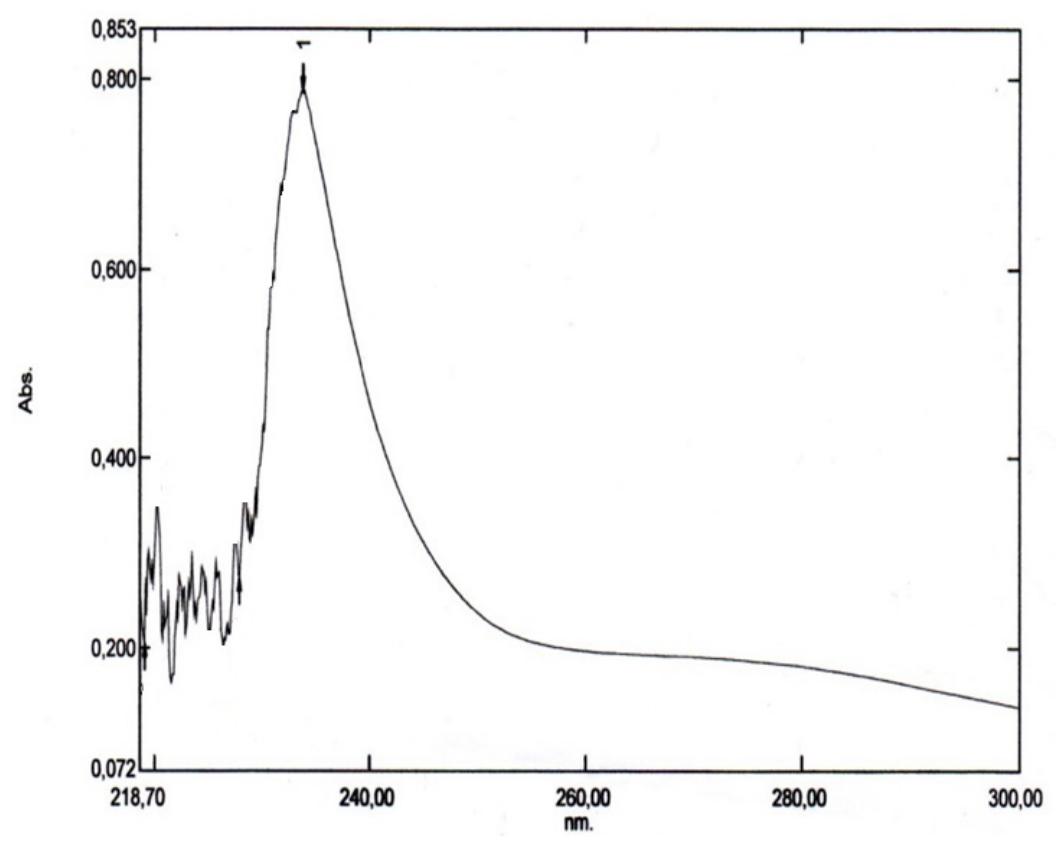

FIGURE 3. UV absorption spectra of CHL from fishbone

\section{FTIR SPECTRA OF CHL FROM FISHBONE}

FTIR data results from CHL have similarities to the peak absorption of FTIR spectra obtained by Kong and Yu (2007), Liang et al. (2014), Muyonga et al. (2004), Pal and Suresh (2017), and Zhao et al. (2018). The FTIR spectrum of CHL showed the presence of Amide A and
B groups, and Amide I, II, and III groups (Figure 4). The spectra area that shows the presence of collagen can be seen in Table 1. Based on Figure 4, it can be seen that CHL from fishbone contains the Amide A group with a vibration peak at wavenumber $3444.87 \mathrm{~cm}^{-1}$ where $\mathrm{N}-\mathrm{H}$ stretching of the amide group is associated with the O-H bonding of hydroxyproline (Pal \& Suresh 2017; Zhao et 
al. 2018). Then, the peak at wavenumber $2924.09 \mathrm{~cm}^{-1}$ in CHL indicates the presence of the Amide B group. Kong and $\mathrm{Yu}$ (2007) reported that the Amide B vibration was formed from the asymmetrical stretching of $\mathrm{CH}_{2}$. Furthermore, there is a peak at wavenumber 1618.28 $\mathrm{cm}^{-1}$ in CHL indicating the presence of Amide group I. Zhao et al. (2018) reported that the presence of the Amide I group showed the presence of $\mathrm{C}=\mathrm{O}$ bonds which are characteristic of the collagen polypeptide skeleton. The peak at wavenumber $1566.2 \mathrm{~cm}^{-1}$ in $\mathrm{CHL}$ indicates the presence of Amide II. Kong and Yu (2007) reported that Amide II is associated with the presence of stretching C-N and N-H bending groups. The presence of a peak at wavenumber $1244.09 \mathrm{~cm}^{-1}$ in collagen indicates the presence of the Amide III group, which correlates with the presence of a pyrrolidine ring on proline and hydroxyproline amino acids (Matmaroh et al. 2011; Pal \& Suresh 2017). The presence of Amides II and III in the CHL shows that the helical structure of the resulting collagen has the characteristics of a triple helix collagen (Muyonga et al. 2004).

TABLE 1. FT-IR spectra peak locations and their assignment for CHL from fishbone

\begin{tabular}{|c|c|c|c|c|}
\hline \multirow{2}{*}{ Region } & \multicolumn{2}{|c|}{ Wavenumber $\left(\mathrm{cm}^{-1}\right)$} & \multirow{2}{*}{ Assignment } & \multirow{2}{*}{ Reference } \\
\hline & CHL & Vibration area & & \\
\hline Amide A & 3446 & $3300-3500$ & N-H stretching coupled with hydrogen bonding & (Muyonga et al. 2004) \\
\hline Amide B & 2924 & $2915-2935$ & $\begin{array}{c}\text { Asymmetrical stretching } \mathrm{CH}_{2} \text { asymmetrical } \\
\text { stretching }\end{array}$ & (Muyonga et al. 2004) \\
\hline- & 2852 & $2800-2900$ & $\mathrm{CH}_{3}$-symmetric stretch: mainly proteins & (Pal \& Suresh 2017) \\
\hline Amide I & 1618 & $1600-1700$ & $\mathrm{C}=\mathrm{O}$ stretch/hydrogen bond coupled with $\mathrm{COO}-$ & (Pal \& Suresh 2017) \\
\hline- & 1743 & $1600-1700$ & $\mathrm{C}=\mathrm{O}$ stretch/hydrogen bond coupled with $\mathrm{COO}-$ & (Liang et al. 2014) \\
\hline Amide II & 1566 & $1480-1575$ & $\mathrm{NH}$ bend coupled with $\mathrm{CN}$ stretching & (Muyonga et al. 2004) \\
\hline- & 1456 & - & $\mathrm{CH}_{2}$-asymmetric bending & (Pal \& Suresh 2017) \\
\hline- & 1421 & - & COO-symmetrical stretch & (Pal \& Suresh 2017) \\
\hline Amide III & 1244 & $1229-1301$ & $\mathrm{NH}$ bend coupled with $\mathrm{CN}$ stretch & $\begin{array}{c}\text { (Liang et al. 2014); (Muyonga } \\
\text { et al. 2004) }\end{array}$ \\
\hline- & 1099 & - & C-O Stretching & (Pal \& Suresh 2017) \\
\hline- & 1056 & - & C-O Stretching & (Pal \& Suresh 2017) \\
\hline- & 1029 & - & C-O Stretching & (Pal \& Suresh 2017) \\
\hline- & 659 & - & Skeletal stretching & (Liang et al. 2014) \\
\hline
\end{tabular}




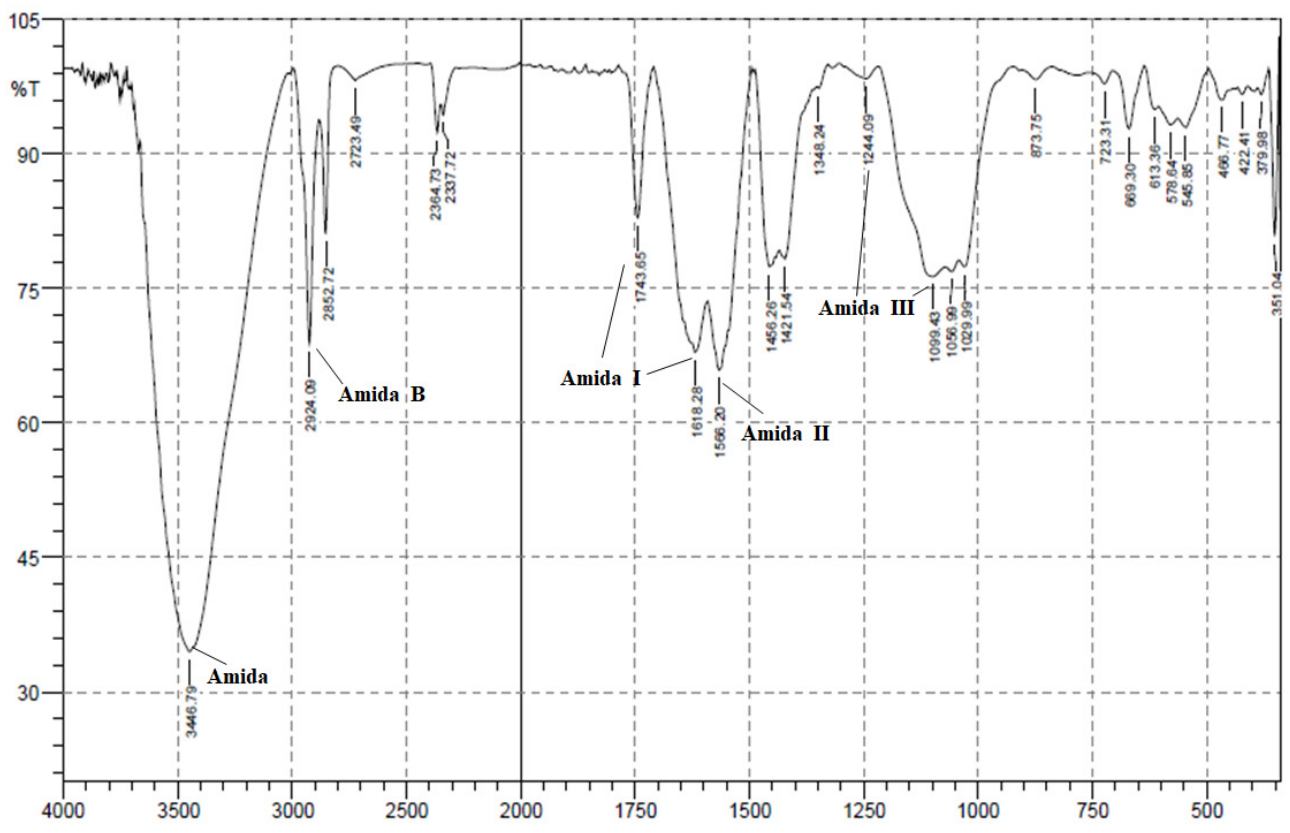

FIGURE 4. FTIR spectrum of CHL from fishbone

\section{DPPH RADICAL SCAVENGING ACTIVITY OF CHL}

The antioxidant activity assay of CHL from lamuru fishbone was carried out using the DPPH radical scavenging method. The DPPH radical scavenging method was chosen because it requires a small volume of samples, and is simple, easy, fast and sensitive when evaluating the antioxidant activity of natural compounds. The mechanism of this method is based on the fact that DPPH will be reduced by the hydrogen or electron donation process so that the color will change from violet to yellow with color intensity proportional to the number of electron donations followed by a decrease in absorbance (Nur et al. 2019; Prakash et al. 2007). Determination of the maximum wavelength optimization of DPPH solution was done at $515 \mathrm{~nm}$, because DPPH radicals can be detected at this wavelength (Prakash et al. 2007). The antioxidant activity of collagen hydrolysate is influenced by its amino acid composition. Collagen hydrolysate contains aromatic amino acids which have an antioxidant role (Chi et al. 2015; Ulagesan et al. 2018). The results show that the antioxidant activity of CHL using DPPH radical scavenging method has an IC50 value of 495.5 $\mu \mathrm{gmL}-1$. This shows that concentration of $495.5 \mu \mathrm{gmL}-1$ can inhibit DPPH radical activity by $50 \%$. At the highest concentration $(500 \mu \mathrm{gmL}-1)$, the CHL provided DPPH radical reduction activity reached $51.45 \pm 1.24 \%$ (Figure $5)$. Figure 5 shows a trend of increasing the percentage of inhibition of CHL with increasing concentrations of sample solution. The amount of antioxidant activity of CHL from fishbone has similarities to the research conducted by Liu et al. (2012) and Wang et al. (2013) about collagen hydrolysates from cod skin and scales of croceine croaker, respectively.

\section{FERRIC REDUCTION ANTIOXIDANT POWER (FRAP) OF CHL}

The antioxidant activity of CHL was also tested by the ferric reduction antioxidant power (FRAP) method. The antioxidant activity test using the FRAP method can determine the total antioxidant content of an ingredient based on the ability of antioxidant compounds to reduce $\mathrm{Fe}^{3+}$ ions to $\mathrm{Fe}^{2+}$. Consequently, the antioxidant power 


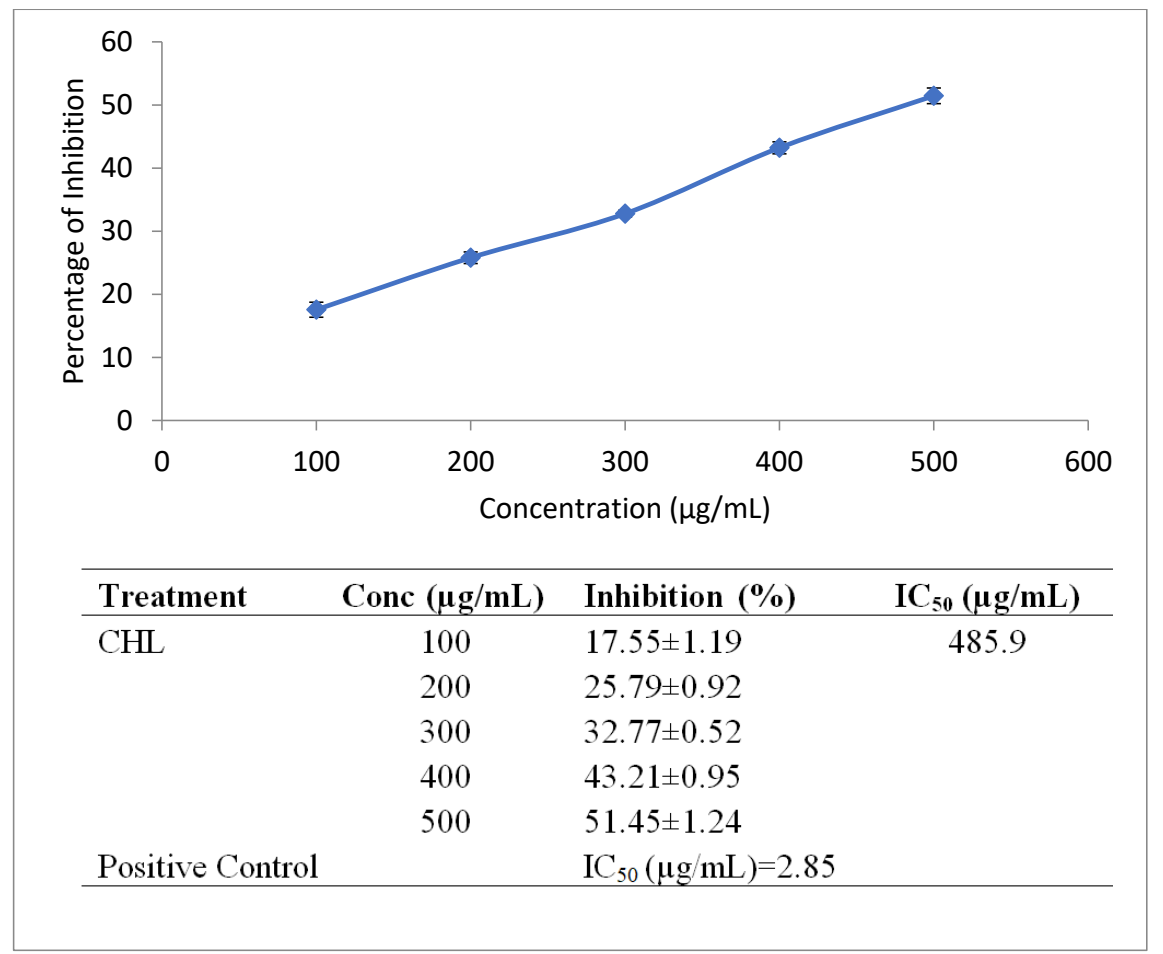

FIGURE 5. Graph of DPPH radical scavenging activity of CHL fishbone as the sample and ascorbic acid as the positive control. The data of percentage inhibition were expressed as mean \pm SD with triplicate $(n=3)$

of a compound is analogous to the ability to reduce that compound. The ability to reduce from a sample is characterized by an increase in the intensity of the color to Prussian blue from the sample solution (Apak et al. 2007; Nur et al. 2019). The reducing power of a sample shows its ability as an electron donor and that it can react with radicals to convert it to a stable form and end the radical chain (Apak et al. 2007). The determination of antioxidant capacity was calculated as $\mathrm{FeSO}_{4}$ using a standard curve which is equivalent to $\mathrm{Fe}^{2+}$. Determination of the antioxidant activity of the FRAP method was based on a linear regression equation from the standard $\mathrm{FeSO}_{4}$ curve. Furthermore, from the absorbance data obtained, its antioxidant activity can be seen using the standard curve equation. From the results obtained, the antioxidant activity of CHL (FRAP value) was able to reduce $\mathrm{Fe}^{3+}$ to $\mathrm{Fe}^{2+}$ by $711.27 \mu \mathrm{M} / \mathrm{g}$. The greater the FRAP value of a sample, the greater the antioxidant activity.

\section{THE $\alpha$-GLUCOSIDASE INHIBITORY ACTIVITY}

The collagen hydrolysate was then tested for $\alpha$-glucosidase inhibitory activity. This test was performed using the colorimetric method in which p-nitrophenyl-D-glucopyranoside ( $\mathrm{pNPG}$ ) as a substrate is hydrolyzed into p-nitrophenol and D-glucose compounds by the $\alpha$-glucosidase enzyme, causing a yellow color change (Cihan et al. 2010). The higher the intensity of the yellow color in the solution, the more p-nitrophenol has been formed. The presence of 
collagen hydrolysate is expected to inhibit the binding of the substrate to enzymes, meaning that the intensity of the yellow color produced will fade (Cihan et al. 2010). The IC50 values describe the concentration of CHL needed to inhibit $50 \%$ of the $\alpha$-glucosidase enzyme activity under test conditions. The smaller the IC50 value, the better the quality of the enzyme inhibition (McPherson 2011). This indicates that the smaller the IC50 value, the more potent its compound. In our research, acarbose was used as a positive control, as this has been widely used as an inhibitor of the $\alpha$-glucosidase enzyme, and a negative control that is a mixture of buffer, substrate, and enzyme without the addition of inhibitors. The absorption of samples was measured using a microplate reader at a maximum wavelength of $405 \mathrm{~nm}$. The results obtained are shown in Table 2.

TABLE 2 . The $\alpha$-glucosidase inhibitory activity of CHL fishbone

\begin{tabular}{|c|c|c|c|c|c|c|c|}
\hline \multirow{6}{*}{$\begin{array}{l}\text { Sample } \\
\text { CHL* }\end{array}$} & $\begin{array}{c}\text { Conc. }(\mu \mathrm{g} / \\
\mathrm{mL})\end{array}$ & Inhibition (\%) & $\begin{array}{c}\mathrm{IC}_{50} \\
(\mathrm{mg} / \mathrm{mL})\end{array}$ & \multirow{6}{*}{$\begin{array}{c}\text { Positive } \\
\text { Control** }\end{array}$} & $\begin{array}{c}\text { Conc. }(\mu \mathrm{g} / \\
\mathrm{mL})\end{array}$ & Inhibition (\%) & $\begin{array}{c}\mathrm{IC}_{50} \\
(\mu \mathrm{g} / \mathrm{mL})\end{array}$ \\
\hline & 100 & $17.41 \pm 0.25$ & \multirow{5}{*}{574} & & 2.5 & $32.25 \pm 0.37$ & \multirow{5}{*}{5.82} \\
\hline & 200 & $22.54 \pm 0.99$ & & & 5 & $45.54 \pm 0.98$ & \\
\hline & 300 & $30.74 \pm 0.46$ & & & 7.5 & $63.91 \pm 0.93$ & \\
\hline & 400 & $33.23 \pm 0.39$ & & & 10 & $71.05 \pm 0.23$ & \\
\hline & 500 & $47.81 \pm 0.36$ & & & 12.5 & $72.75 \pm 068$ & \\
\hline
\end{tabular}

The data were express as mean \pm SD with triplicate $(n=3) . *$ Collagen hydrolysate from fishbone as sample. **Acarbose as positive control

Table 2 shows that the CHL sample and acarbose have $\mathrm{IC}_{50}$ values of 574 and $5.82 \mu \mathrm{g} / \mathrm{mL}$, respectively. This shows that CHL, with a concentration of $574 \mu \mathrm{g} /$ $\mathrm{mL}$, was able to inhibit the activity of $\alpha$-glucosidase by $50 \%$. This is different from acarbose as a positive control which, at a concentration of $5.82 \mu \mathrm{g} / \mathrm{mL}$, can inhibit the activity of $\alpha$-glucosidase by $50 \%$. The inhibitory activity of CHL is lower than that of acarbose which is likely to be affected because the collagen hydrolysate obtained has not yet been purified. Nevertheless, CHL from fishbone can inhibit the activity of the $\alpha$-glucosidase enzyme with the result that it can be used as a supportive therapy for the treatment of diabetes mellitus.

\section{CONCLUSION}

The extraction, isolation and hydrolysis process of collagen from lamuru (Caranx ignobilis) fishbone has been successfully carried out and classified as collagen type I. the collagen hydrolysates that have been obtained have good antioxidant activity and are able to inhibit the enzyme $\alpha$-glucosidase so that it can be developed as a remedy for a variety of disorders caused by oxidative stress, such as diabetes mellitus.

\section{ACKNOWLEDGEMENTS}

The author is very grateful to Sekolah Tinggi Ilmu Farmasi Makassar for providing research funding.

\section{REFERENCES}

Abuine, R., Rathnayake, A.U. \& Byun, H.G. 2019. Biological activity of peptides purified from fish skin hydrolysates. Fisheries and Aquatic Sciences 22(2): 1-14.

Apak, R., Guclu, K., Demirata, B., Ozyurek, M., Celik, S.E., Bektasoglu, B., Berker, K.I. \& Ozyurt, D. 2007. Comparative 
evaluation of various total antioxidant capacity assays applied to phenolic compounds with the CUPRAC assay. Molecules 12(7): 1496-1547.

Bousopha, S., Nalinanon, S. \& Sriket, C. 2016. Production of collagen hydrolysate with antioxidant activity from pharaoh cuttlefish skin. Chiang Mai University Journal of Natural Sciences 16(15(2)): 151-162.

Byun, H.G. \& Kim, S.K. 2001. Purification and characterization of angiotensin I converting enzyme (ACE) inhibitory peptides from Alaska pollack (Theragra chalcogramma) skin. Process Biochemistry 36(12): 1152-1162.

Carvalho, A.M., Marques, A.P., Silva, T.H. \& Reis, R.L. 2018. Evaluation of the potential of collagen from codfish skin as a biomaterial for biomedical applications. Marine Drugs 16(12): 495.

Chi, C.F., Hu, F.Y., Wang, B., Li, Z.R. \& Luo, H.Y. 2015. Influence of amino acid compositions and peptide profiles on antioxidant capacities of two protein hydrolysates from skipjack tuna (Katsuwonus pelamis) dark muscle. Marine Drugs 13(5): 2580-2601.

Cihan, A.C., Ozcan, B., Bubenheim, N.T. \& Cokmus, C. 2010. Characterization of a thermostable $\alpha$-glucosidase from Geobacillus thermodenitrificans F84a. In Current Research, Technology and Education Topics in Applied Microbiology and Microbial Biotechnology. Spain: Research Center, Badajoz. pp. 945-955.

deMan, J.M. 1999. Protein. Principles of Food Chemistry. New York: Springer. pp. 111-162.

Ding, D., Du, B., Zhang, C., Zaman, F. \& Huang, Y. 2019. Isolation and identification of an antioxidant collagen peptide from skipjack tuna (Katsuwonus pelamis) bone. RSC Advances 9: 27032-27041.

Elya, B., Basah, K., Mun'im, A., Yuliastuti, W., Bangun, A. \& Septiana, E.K. 2012. Screening of $\alpha$-glucosidase inhibitory activity from some plants of Apocynaceae, Clusiaceae, Euphorbiaceae, and Rubiaceae. Journal of Biomedicine and Biotechnology 2012: 281078.

Gómez-Guillén, M.C., Turnay, J., Fernandez-Diaz, M.D., Ulmo, N., Lizarbe, M.A. \& Montero, P. 2002. Structural and physical properties of gelatin extracted from different marine species: A comparative study. Food Hydrocolloids 16(1): 25-34.

Haniffa, M.A.K., Sheela, P.A.Y., Kavitha, K. \& Jais, A.M.M. 2014. Salutary value of haruan, the striped snakehead Channa striatus - a review. Asian Pacific Journal of Tropical Biomedicine 4(Supplement 1): S8-S15.

Haque, E. \& Chand, R. 2008. Antihypertensive and antimicrobial bioactive peptides from milk proteins. European Food Research and Technology 227(1): 7-15.

Hong, G.P., Min, S.G. \& Jo, Y.J. 2019. Anti-oxidative and anti-aging activities of porcine by-product collagen hydrolysates produced by commercial proteases: Effect of hydrolysis and ultrafiltration. Molecules 24(6): 1104.
Hoyer, B., Bernhardt, A., Lode, A., Heinemann, S., Sewing, J., Klinger, M., Notbohm, H. \& Gelinsky, M. 2014. Jellyfish collagen scaffolds for cartilage tissue engineering. Acta Biomaterialia 10(2): 883-892.

Iba, Y., Yokoi, K., Eitoku, I., Goto, M., Koizumi, S., Sugihara, F., Oyama, H. \& Yoshimoto, T. 2016. Oral administration of collagen hydrolysates improves glucose tolerance in normal mice through GLP-1-dependent and GLP-1independent mechanisms. Journal of Medicinal Food 19(9): 836-843.

Jamilah, B., Razali, U.H.M., Hashim, D. \& Sazili, A.Q. 2013. Properties of collagen from barramundi (Lates calcarifer) skin. International Food Research Journal 20(2): 791798.

Kim, S.K. \& Mendis, E. 2006. Bioactive compounds from marine processing byproducts - a review. Food Research International 39(4): 383-393.

Kong, J. \& Yu, S. 2007. Fourier transform infrared spectroscopic analysis of protein secondary structures. Acta Biochimica et Biophysica Sinica 39(8): 549-559.

Konrad, B., Anna, D., Marek, S., Marta, P., Aleksandra, Z. \& Jozefa, C. 2014. The evaluation of dipeptidyl peptidase (DPP)-IV, $\alpha$-glucosidase and angiotensin converting enzyme (ACE) inhibitory activities of whey proteins hydrolyzed with serine protease isolated from Asian pumpkin (Cucurbita ficifolia). International Journal of Peptide Research and Therapeutics 20(4): 483-491.

León-López, A., Fuentes-Jimenez, L., Hernandez-Fuentes, A.D., Campos-Montiel, R.G. \& Aguirre-Alvarez, G. 2019. Hydrolysed collagen from sheepskins as a source of functional peptides with antioxidant activity. International Journal of Molecular Sciences 20(16): 3931

Liang, Q., Wang, L., Sun, W., Wang, Z., Xu, J. \& Ma, H. 2014. Isolation and characterization of collagen from the cartilage of Amur sturgeon (Acipenser schrenckii). Process Biochemistry 49(2): 318-323.

Liu, F., Liu, C.E., Lorena, D., Xiaoshuan, Z. \& Fu, Z. 2012. Evaluation of the antioxidant activity of collagen peptide additive extracted from cod skin. Journal of Environmental Protection and Ecology 13(3): 1836-1841.

Liu, H., Li, D. \& Guo, S. 2007. Studies on collagen from the skin of channel catfish (Ictalurus punctaus). Food Chemistry 101(2): 621-625.

Lorenzo, J.M., Munekata, P.E.S., Gomez, B., Barba, F.J., Leticia, M., Perez-Santaescolastica, C. \& Fidel, T.V. 2018. Bioactive peptides as natural antioxidants in food products - a review. Trends in Food Science \& Technology 79: $136-147$.

Lowry, O.H., Rosebrough, N.J., Farr, A.L. \& Randall, R.J. 1951. Protein measurement with the Folin phenol reagent. The Journal of Biological Chemistry 193: 265-275.

Mahboob, S. 2014. Isolation and characterization of collagen from fish waste material - skin, scales and fins of Catla 
catla and Cirrhinus mrigala. Journal of Food Science and Technology 52(7): 4296-4305.

Matmaroh, K., Benjakul, S., Prodpran, T., Encarnacion, A.B. \& Kishimura, H. 2011. Characteristics of acid soluble collagen and pepsin soluble collagen from scale of spotted golden goatfish (Parupeneus heptacanthus). Food Chemistry 129(3): 1179-1186.

McPherson, R.A. 2011. Specific proteins. In Henry's Clinical Diagnosis and Management by Laboratory Methods, edited by McPherson, R.A. \& Pincus, M.R. Elsevier Health Sciences.

Mocan, E., Tagadiuc, O. \& Nacu, V. 2011. Aspects of collagen isolation procedure. Clinical Research Studies 320: 1-5.

Muyonga, J.H., Cole, C.G.B. \& Duodu, K.G. 2004. Characterisation of acid soluble collagen from skins of young and adult Nile perch (Lates niloticus). Food Chemistry 85(1): 81-89.

Nasri, R., Younes, I., Jridi, M., Trigui, M., Bougatef, A., NedjarArroume, N., Dhulster, P., Nasri, M. \& Chaabouni, M.K. 2013. ACE inhibitory and antioxidative activities of Goby (Zosterissessor ophiocephalus) fish protein hydrolysates: Effect on meat lipid oxidation. Food Research International 54(1): 552-561.

Nur, S., Jannah, C., Winarni, D., Rahman, D.A., Hamdayani, L.A. \& Sami, F.J. 2019. Total phenolic and flavonoid compounds, antioxidant and toxicity profile of extract and fractions of paku atai tuber (Angiopteris ferox Copel). Food Research 3(6): 734-740.

Ogawa, M., Moody, M.W., Portier, R.J., Bell, J., Schexnayder, M.A. \& Losso, J.N. 2003. Biochemical properties of black drum and sheepshead seabream skin collagen. Journal of Agricultural and Food Chemistry 51(27): 8088-8092.

Pal, G.K. \& Suresh, P.V. 2017. Comparative assessment of physico-chemical characteristics and fibril formation capacity of thermostable carp scales collagen. Materials Science and Engineering C 70: 32-40.

Pati, F., Adhikari, B. \& Dhara, S. 2010. Isolation and characterization of fish scale collagen of higher thermal stability. Bioresource Technology 101(10): 3737-3742.

Poppe, J. 1992. Gelatin. In Thickening and Gelling Agent for Food, edited by Imeson, A. Switzerland: Springer. pp. 98-123.

Prakash, D., Suri, S., Upadhyay, G. \& Singh, B.N. 2007. Total phenol, antioxidant and free radical scavenging activities of some medicinal plants. International Journal of Food Sciences and Nutrition 58(1): 18-28.

Silvestre, M.P.C., Morais, H.A., Silva, V.D.M. \& Silva, M.R. 2013. Degree of hydrolysis and peptide profile of whey proteins using pancreatin. Nutrire 38(3): 278-290.

Ulagesan, S., Kuppusamy, A. \& Kim, H.J. 2018. Antimicrobial and antioxidant activities of protein hydrolysate from terrestrial snail Cryptozona bistrialis. Journal of Applied Pharmaceutical Science 8(12): 12-19.
Wang, B., Wang, Y.M., Chi, C.F., Luo, H.Y., Deng, S.G. \& Ma, J.Y. 2013. Isolation and characterization of collagen and antioxidant collagen peptides from scales of croceine croaker (Pseudosciaena crocea). Marine Drugs 11(11): 4641-4661.

Yu, Z., Yin, Y., Zhao, W., Yu, Y., Liu, B., Liu, J. \& Chen, F. 2011. Novel peptides derived from egg white protein inhibiting alpha-glucosidase. Food Chemistry 129(4): 1376-1382.

Zayas, J.F. 1997. Solubility of proteins. In Functionality of Proteins in Food, edited by Zayas, J.F. Berlin, Heidelberg: Springer Berlin Heidelberg. pp. 6-75.

Zhang, J., Duan, R., Ye, C. \& Konno, K. 2010. Isolation and characterization of collagens from scale of silver carp (Hypophthalmichthys molitrix). Journal of Food Biochemistry 34(6): 1343-1354.

Zhao, Y., Wang, Z., Zhang, J. \& Su, T. 2018. Extraction and characterization of collagen hydrolysates from the skin of Rana chensinensis. AGRIS 8(3): 1-8.

Zhou, P. \& Regenstein, J.M. 2005. Effects of alkaline and acid pretreatments on Alaska pollock skin gelatin extraction. Journal of Food Science 70(6): c392-c396.

Zhuang, Y., Sun, L., Zhang, Y. \& Liu, G. 2012. Antihypertensive effect of long-term oral administration of jellyfish (Rhopilema esculentum) collagen peptides on renovascular hypertension. Marine Drugs 10(2): 417-426.

Syamsu Nur*, Yogillverd Wierson, Fitriyanti Jumaetri Sami, Megawati \& Sahibuddin A. Gani

Department of Pharmaceutical Chemistry

Sekolah Tinggi Ilmu Farmasi Makassar

90242 Daya Makassar

Indonesia

Andi Nur Aisyah

Department of Pharmaceutical Technology

Sekolah Tinggi Ilmu Farmasi Makassar

90242 Daya Makassar

Indonesia

Yulia \& Marwati

Department of Pharmaceutical Biology

Sekolah Tinggi Ilmu Farmasi Makassar

90242 Daya Makassar

Indonesia

*Corresponding author; email: syamsunur19@gmail.com

Received: 10 February 2020

Accepted: 18 December 2020 